\title{
Ethnobotanical Survey of Uses of Leguminosae in Raipur District
}

\author{
Dewangan $\mathrm{P}^{*}$ and Acharya $\mathrm{V}$ \\ Research scholar, Govt. D.B Girls P.G. College, Raipur (C.G.) \& *Asst. Prof. Botany, Govt. D.B Girls P.G. \\ College, Raipur (C.G.)
}

\begin{abstract}
Plants have been the part of life forms even with the progenitors of man. Term "Ethnobotany" was coined to denote use of plants by human being.Ethnobotany deals with the direct relationship of plants with man. The term today has come to denote the entire realm of direct relationship between plant and man. Plants show enormous diversity in the form of Algae, Fungi, Bryophytes, Pteridophytes, Gymnosperms, and Angiosperms of which later are the most diversified plants. Present study focuses on ethnobotanical study of one of the largest family of Angiosperms, the family Leguminosae, of Raipur city area. Leguminosae include three subfamilies viz: Papilionoideae, Caesalpinoideae and Mimosoideae. The family has approximately 18,000 species grouped into around 650 genera with cosmopolitan distribution. During the study seasonal field survey has been made. Information about the plants were obtained by interviewing the common people and folk healers. During the study 8 plant species were found to be used as pulses, 2 plant species (Glycine max andArachis hypogea) as edible oil yielding plants, 9 plant species used in different socio religious ceremonies (eg. Butea monosperma, Acacia catechu,Prosopis cineraria, Acacia pycnthus, Vigna sps ), 7 plant species as vegetable (eg. Trigonellafoenum-graecum), 3 species as dye yielding plants (e.g. Butea monosperma), 26 plants used in traditional medicine (e.g Cassia occidentalis, Acacia concinna, Psoralea corylifolia, Dolichos biflorus, Mucuna pruriens), 7 plants species are Non-wood Forest Produces (NWFPs), (e.g. Acacia nilotica), 13 plants are used as timber yielding plants e.g. Dalbergia sissoo). Some are fodder plants (e.g. Leucaena leucophloea) and 2 plant species are used as tooth brush (e.gAcacia nilotica) and some plants yields fibre. Some Weeds of this family are used to increase the fertility of soil due to the capacity of nitrogen fixation eg. Aeshchynomene indica, and Lathyrus odoratus. Conservation practices of plants of this family have been observed during the present studies.
\end{abstract}

Keywords: Leguminosae, ethnobotany, herbal medicine.

\section{Introduction}

Present work focuses on Ethnobotanical importance of plants of Raipur (Chhattisgarh) belonging to Plant family Leguminosae. Since human starts discovering uses of plants from ancient times its use are integral part of human life from then. Use of plants by human in various ways approach a term "Ethnobotany". Ethnobotany term was first used by a botanist Harshberger(1895) to describe his work- "Plants used by primitive and aboriginal people". The first definition provided by Harshberger is "how native tribes use plants for food, shelter, or clothing". Some of the work in ethnobotanical aspect of plants have been done by Ambasta $(1986)^{2}$, Dastar(1964) ${ }^{4}$, Agharkar(1991) ${ }^{1}, \operatorname{Cotton}(1996)^{3}$, Jain $(1995)^{9}$.

Leguminosae is third largest family of flowering plants after Asteraceae and Orchidaceae. Leguminosae include three subfamilies- Papilionoideae, Caesalpinoideae and Mimosoideae (Bentham\&Hooker $1862-1883)^{7}$. It has approximately 18,000 species classified into around 650 genera. In India 18 genera and 70 species of Mimosoideae have identified and is the smallest subfamily of Leguminosae. 17 genera and 90 species of Caesalpinioideae are identified in India which is distributed in tropical and sub tropical regions. Papilionoideae is the largest family with about 35 genera and 250 species.Many workers have worked about this family, some of them are Martin(1963) ${ }^{12}$, Duke $(1986)^{5}$, Sanjappa $(1992)^{16}$, Lewis, Schrire, Mackinder $(2005)^{11}$, Nair and Khanna(2005) ${ }^{13}$.

Study Area: Raipur is the capital of the state of Chattisgarh with the Mahanadi River to its east and thick forests to the south.Chattisgarh is second densely forested state of India after Assam. The state lies between $17^{\circ} 46^{\prime}-$ $24^{\circ} 5^{\prime}$ north latitude and $80^{\circ} 15^{\prime}-84^{\circ} 20^{\prime}$ east longitude. Total area of the state is $1,46,361 \mathrm{sq} \mathrm{km}$. On the northwest of Raipur rises the Maikal hill, the land rises and merges with the Chota Nagpur Plateau.The state receives an average rainfall of $150 \mathrm{~cm}$. Different areas of the district like Forest areas, urban areas, roadside, wastelands, and grasslands, agricultural fields of the study area were surveyed. Temperature of the area raises to $45^{\circ} \mathrm{C}$ in Summer and goes down to $8^{\circ} \mathrm{C}$ in Winter. Soil in the area is red soil which is quite fertile. 


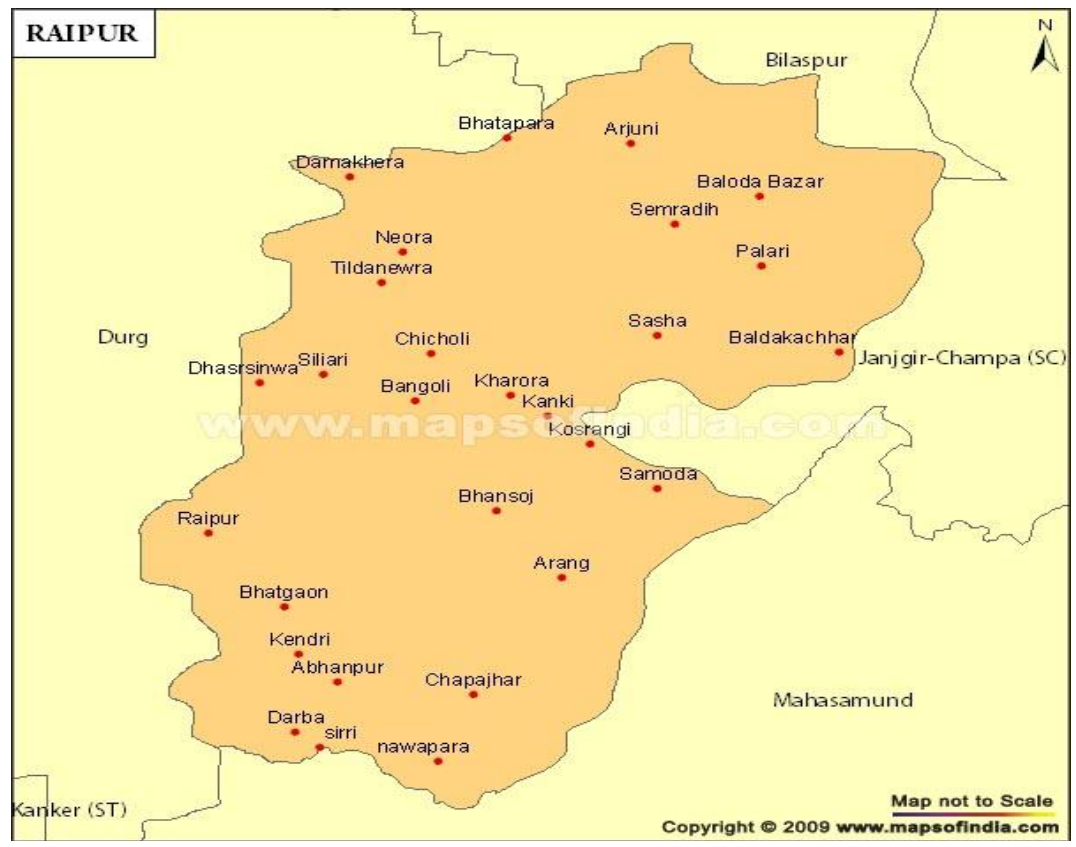

Fig:1- Map of study area - Raipur distict

\section{Materials And Methods}

Periodic field visits were undertaken to the study area for identification and collection of plants. The survey has been done for a period of from June 2014-August 2015. Local people, folk healers were interviewed during the survey. Total 125 People were interviewed with the help of questionnaire including 22 folk healers. Out of 125 people 82 were male and 43 were female. Detailed information regarding the local name of plants, their uses was recorded. Also habit, habitat, soil type, date of the field visit were recorded. Plant samples were collected for herbarium preparation. Herbarium specimens were prepared as per the methodology of Jain and Rao (1977). For identification of plants flora of Hooker $(1872-97)^{7}$, flora of Duthie $(1903)^{6}$, flora of Verma, Pant and Hanfi (1985) ${ }^{19}$, flora of Panigrahi and Murti (1999) ${ }^{15}$, flora of Verma, D.M., N.P. Balkrishan and R.D. Dixit $(1994)^{20}$, Oommachan $(1976)^{14}$ have been considered.

\section{Observation And Result:}

The observations made in different regions and localities of the study area have been recorded, information and data gained during the survey are enlisted below:

\begin{tabular}{|c|c|c|c|}
\hline \multicolumn{4}{|c|}{ Table-1: Leguminous plants used as food: } \\
\hline Common name & Botanical Name & Used as & Part used \\
\hline Mungfali & Arachis hypogaea L. & Food grain/edible oil yielding & Seeds \\
\hline Arhar & Cajanus cajan (L.) Millsp. & Pulses (source of protein) & Legume \\
\hline Charota & Cassia tora $\mathrm{L}$. & Vegetable & Leaves \\
\hline Kasondi & Cassia occidentalis L. & Vegetable & Leaves \\
\hline Chana & Cicer arietinum $\mathrm{L}$. & Pulses & Legume \\
\hline Gavarphalli & Cyamopsis tetragonoloba (L.) Taub. & Vegetable & Legume \\
\hline Sem & Dolichos lablab L. & Vegetable & Legume \\
\hline Soyabean & Glycine max Merr. & Pulses/edible oil & Legume \\
\hline Tiwra & Lathyrus odoratus L. & Pulses/ vegetable & Legume \\
\hline Masura & Lens esculenta Moench. & Pulses & Legume \\
\hline Urd & Phaseolus radiatus $\mathrm{R}$. & Pulses & Legume \\
\hline Mung & Phaseolus mungo Hepper & Pulses & Legume \\
\hline Matar & Pisum sativum L. & Pulses & Legume \\
\hline Ganga imli & Pithecellobium dulce (Roxb.) Benth. & Fruit & Legume \\
\hline Vidarikand & Pueraria tuberosa DC & Tuber & Tuber \\
\hline Imli & Tamarindus indica L. & Fruit & Legume \\
\hline Methi & Trigonella foenum-graecum $\mathrm{L}$. & Spice & Leaves \\
\hline Barbatti & Vigna unguiculata $\mathrm{L}$. & Vegetable & Legume \\
\hline August /Baakphool & Sesbania grandiflora (L) Poiret & Vegetable & Flower \& leaves \\
\hline
\end{tabular}




\begin{tabular}{lcll} 
Common name & \multicolumn{1}{c}{ Table-2: Leguminous plant yielding NWFPs: } & \\
Babool & Botanical name & Plant yield & Plant Part \\
Khair & Acacia arabica Willd. & Gum/Datoon & Stem \\
Charota & Acacia catechu Willd. & Kattha/dye & Stem \\
Ganga imli & Cassia tora L. & Gum & Seeds \\
Imli & Pithecellobium dulce (Roxb.) Benth. & Fruit & Fruit \\
Palash & Tamarindus indica L. & Fruit & Fruit \\
Mahulbel & Butea monosperma Lam.) Taub. & Dye & Flower \\
Amaltas & Bauhinia vahlii Wight \&Arn. & Disposable plates & Leaves \\
Shikakai & Cassia fistula L. & Dye & Flower, Fruit \\
Raktamadar & Acacia concinna DC & Fruit & Fruit \\
\hline & Erythrina indica Lam. & Dye & Flower \\
\hline
\end{tabular}

\begin{tabular}{l} 
Common name \\
Australian babool \\
Siris \\
Siris \\
Safed siris \\
Kachnar \\
LalKachnar \\
Amaltash \\
Sissoo \\
Shisham \\
Anjan \\
Ganga imali \\
Bija \\
\hline
\end{tabular}

Table-3: Timber yielding leguminous plants:

$\begin{array}{ll}\text { Botanical name } & \text { Wood Quality } \\ \text { Acacia melanoxylon A.Cunn } & \text { Low quality wood } \\ \text { Albizia lebbeck }(\text { L.) Benth. } & \text { Low quality wood } \\ \text { Albizia odoratissima } \text { Benth. } & \text { Low quality wood } \\ \text { Albizzia procera } \text { (Roxb)Benth. } & \text { Low quality wood } \\ \text { Bauhinia variegata } \text { L. } & \text { Low quality wood } \\ \text { Bauhinia purpurea } \text { L. } & \text { Low quality wood } \\ \text { Cassia fistula } \text { L. } & \text { Low quality wood } \\ \text { Dalbergia sissoo Roxb. } & \text { Good quality wood } \\ \text { Dalbergia latifolia } \text { Roxb. } & \text { High quality wood } \\ \text { Hardwickia binata } \text { Roxb } . & \text { Low quality wood } \\ \text { Pithecellobium dulce } \text { (Roxb.) Benth. } & \text { Low quality wood } \\ \text { Pterocarpus marsupium } \text { Roxb. } & \text { High quality wood }\end{array}$

\section{Common name}

Jand

Kachnar

Mahulbel, Mahulpatta

Kachnar

Salperni

\section{Table-4: Fibre yielding plants of Leguminosae:}

\section{Botanical name}

Acacia leucophloea (Roxb.)

Bauhinia purpurea $\mathrm{L}$.

Bauhinia vahlii Wight \&Arn.

Bauhinia variegata $\mathrm{L}$.

Desmodium gangeticum (L.)
Part used

Stem

Stem

Stem

Stem

Stem

\begin{tabular}{|c|c|c|c|}
\hline \multicolumn{4}{|c|}{ Table-5: Plants used in Socio-religious ceremonies } \\
\hline Common name & Botanical name & Parts used & Ceremony \\
\hline Palash & Butea monosperma (Lam.) Taub. & Flower & Shivratri pooja \\
\hline Kachnar & Bauhinia purpurea $\mathrm{L}$. & Flower, leaves & Dusherra \\
\hline Sonpatti & Bauhinia variegata $\mathrm{L}$. & Leaves & Dusherra \\
\hline Aprajita & Clitoria ternatea $\mathrm{L}$. & Flower & Durga pooja \\
\hline Chana & Cicer arietinum $\mathrm{L}$. & Seeds & Sheetala devi \\
\hline Urd & Phaseolus radiatus $\mathrm{R}$. & Seeds & Shani pooja \\
\hline Mung & Phaseolus mungo Heeper & Seeds & Devi pooja \\
\hline Shami & Prosopis cineraria (L) Druce & Leaves & Shiv pooja \\
\hline
\end{tabular}

Common name
Babool
Shikakai
Katha
Safed Kikar
Kachnar
Palash
Arhar
Senna
Kasondi

Table-6: Plants used in Traditional medicine:

\section{Botanical name}

Acacia arabica Willd.

Acacia concinna DC

Acacia catechu Willd.

Acacia leucophloea Willd.

Bauhinia racemosa Lamk.

Butea monosperma (Lam.) Taub.

Cajanus cajan (L.) Millsp.

Cassia angustifolia Vahl.

Cassia occidentalis $\mathrm{L}$.

\section{Part used}

Stem Bark

Leaves,Fruits

Bark

Bark

Bark

All parts

Leaves, Seeds

Leaves

Leaves

\section{Diseases}

Cough, Dental troubles, Leucorrhoea Gonorrhoea, wounds, skin diseases

Boils, ulcers, Dental trouble

Bronchitis

anti inflammatory

antiviral, jaundice, Piles

Wounds, arbortifacient

Constipation, typhoid, anemia

Skin diseases 


\begin{tabular}{|c|c|c|c|}
\hline Charota bhaji & Cassia tora $L$ & Leaves, pods & Jaundice, dysentry \\
\hline Amaltas & Cassia fistula $\mathrm{L}$. & All parts & Leprosy, rheumatism, cough \\
\hline Gawarphalli & Cyamopsis tetragonoloba $(\mathrm{L}$. & .) Taub.Pods, Gum & Night blindness, asthma \\
\hline Sheesham & Dalbergia latifolia Roxb. & Bark & Leprosy, Diarrhoea \\
\hline Shaalparni & Desmodium gangeticum DC & Root & Fever, vomiting, Vaat Dosh \\
\hline Kulthi & Dolichus biflorus L. & Seeds & postnatal preparation, colic \\
\hline Anjan & Hardwickia binata Roxb. & Bark & Swelling, gonorrhea \\
\hline Masura & Lens esculenta Moench & Seeds & Ulcers, Costipation \\
\hline Laajwanti & Mimosa pudica $\mathrm{L}$ & Leaf & Diarrhoea, Dysentry. piles \\
\hline Kevaanch & Mucuna pruriens DC & Root, Fruit & Kidney stone, Snake bites, fertility \\
\hline Gangaimli & Pithecellobium dulce (Roxb.)Benth. & Bark & Constipation, fever \\
\hline Babchi & Psoralea corylifolia $\mathrm{L}$. & Fruits, Seeds & Bone disorder, Eczema, leucoderma \\
\hline Vidarikand & Pueraria tuberosa DC & Tuber & Cardiac tonic, promotes breast milk \\
\hline Agastya & Sesbania grandiflora $(\mathrm{L})$ Poiret & Leaves, Flower & Nightblindness, Improves eye vision \\
\hline Imli & Tamarindus indica $\mathrm{L}$. & Bark, Leaf & astringent, rheumatic arthritis. \\
\hline Sarphonk & Tephrosia purpurea Pers. & Roots & Dyspepsia, diarrhoea, cough \\
\hline Methi & Trigonella foenum-graecum I & Seeds & Colic, lactogogue \\
\hline
\end{tabular}

\begin{tabular}{|c|c|c|}
\hline \multirow[b]{2}{*}{ Common name } & \multicolumn{2}{|l|}{ Table-7: Ornamental \& Roadside plants: } \\
\hline & Botanical name & Habit \\
\hline Jand & Acacia leucophloea DC & Tree \\
\hline Mangium tree & Acacia mangium Willd. & Tree \\
\hline Australian babool & Acacia melanoxylon R.Br. & Shrub \\
\hline Safedsiris & Albizia lebbeck Benth. & Tree \\
\hline Siris & Albizia odoratissima Benth. & Tree \\
\hline Safedsiris & Albizzia procera (Roxb)Benth. & Tree \\
\hline Kachnar & Bauhinia purpurea $\mathrm{DC}$ & Tree \\
\hline Safedkachnar & Bauhinia vahlii W\&A. & Tree \\
\hline Kachnar & Bauhinia variegata Linn. & Tree \\
\hline Palash & Butea monosperma (Lam.) Taub & Tree \\
\hline Krishanchura & Caesalpinia pulcherrima Swtz & Shrub \\
\hline Calliandra & Calliandra haematocephala Hassk. & Shrub \\
\hline Amaltash & Cassia fistula $\mathrm{L}$. & Tree \\
\hline Kassod & Cassia siamea Lam. & Tree \\
\hline Aprajita & Clitoria ternatea Linn. & Herb \\
\hline SafedGulmohar & Delonix elata $(\mathrm{L}.) \mathrm{Gamble}$ & Tree \\
\hline Gulmohar & Delonix regia (Bojer ex Hook.) Raf. & Tree \\
\hline Coral tree & Erythrina indica Lam. & Tree \\
\hline Vilayatishiris & Gliricidia maculeata $\mathrm{L}$. & Tree \\
\hline Lajwanti & Mimosa pudica Linn. & Herb \\
\hline Chanduphul & Parkia biglandulosa $\mathrm{W} \& \mathrm{~A}$ & Tree \\
\hline Copper pod & Peltophorum ferrugineum Benth. & Tree \\
\hline
\end{tabular}

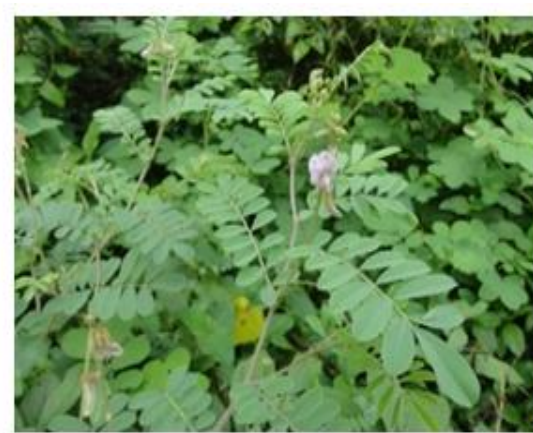

Fig:1-Tephrosia purpurea

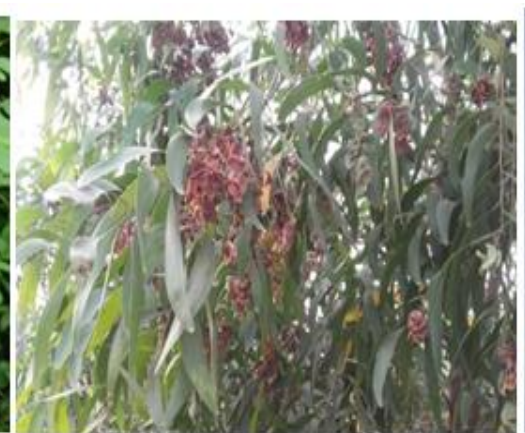

Fig:2-Acacia mangium

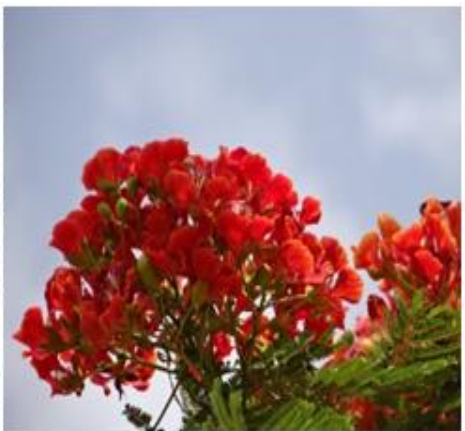

Fig:3-Delonix regia (Bojer) Raf. 


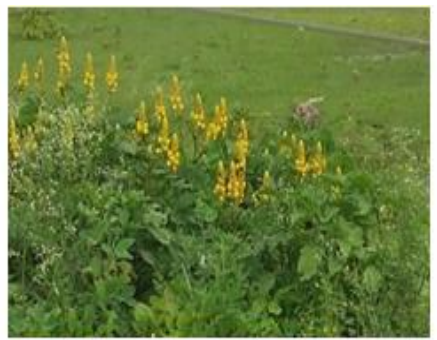

Fig:4-Cassia angustifolia Vahl.

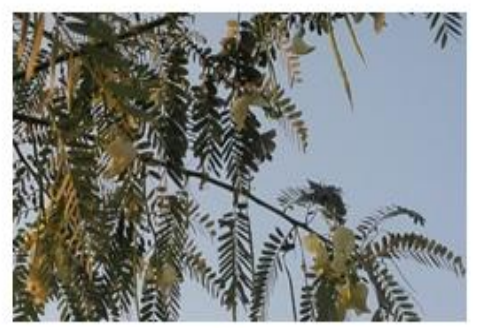

Fig:5-Sesbania grandiflora

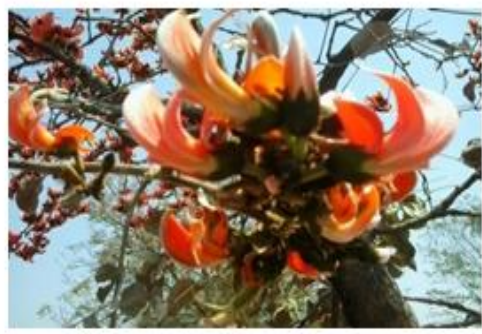

Fig:6-Butea monosperma (Lam.) Taub.

\section{Result And Discussion}

Observation made during the study suggests the use of leguminous ways in different ways. According to the gathered information the number of plants used as pulses in the area is 08, 2 plants are oil yielding plants, 7 plants are used as vegetables, 8 plants are used in socioreligious ceremonies, 26 plants are used in traditional medicine e.g. Pueraria tuberosa, Tephrosia purpurea, 10 plants yield NWFPs, 12 plants are used as timber yielding plants, 3 plants yields dye, 22 plants are ornamental and roadside plants. Total 71 plants are found to be used during the survey.

In addition to this many plants are used as fodder (e.g. Cassia tora, Cassia occidentalis, Leucaena leucocephala, Tephrosia purpurea, Alysicarpus vaginalis, Bauhinia vahii, B. variegate etc) and for fuel wood(Acacia nilotica, Albizia lebbeck, A. procera, Acacia leucophloea, Pithecellobium dulceetc) . The plants used as ornamental and roadside plants are in highest number, next to which is plants used as medicine, preceding plants used in socioreligious ceremonies. The least number of plants are found to be used as edible oil yielding plants.

26 Plant species of Family Leguminosae were found to be used in traditional medicine preparations in the survey area. Some 32 diseases were cured using different parts of these species. Also mode and dosage of the herbal preparation varies with diseases. The data here is based on the information provided by the folkhealers and locals using interview and questionnaire. Also literature is considered to take reference about the plant usage. Plants mentioned here contain secondary metabolites and active principle which are revealed by phytochemical analysis of these plants.

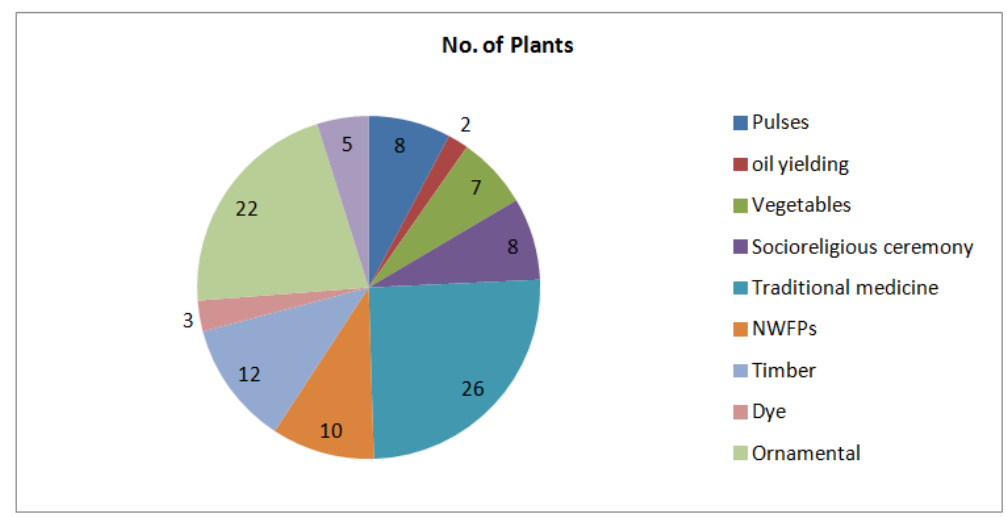

Chart:1 Showing number of plants used for different purposes.

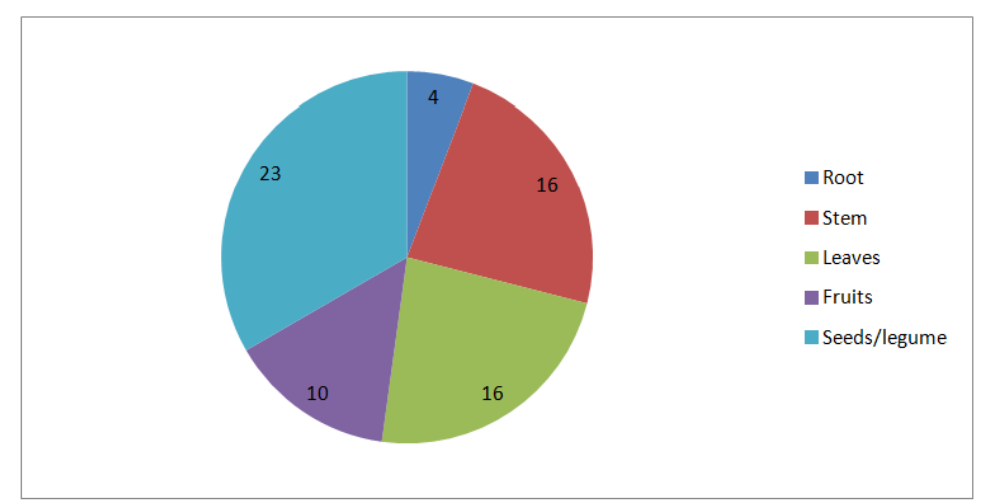

Chart: 2- Morphological constituents of the Plant used in Raipur 


\section{Conclusion}

The present study provides information about diverse uses of leguminous plants in various ways. The documentation of information about ethnobotanical uses of leguminous plants will be prepared for future references. Due to extensive use and habitat destruction wild plants in the area are found low in occurrence. To avoid this, plants can be substituted by another plant for the same purpose after proper assessment. Also information would provide awareness to the people about the uses as in ailments, as fuel, medicine etc. Documentation would help in conservation practices of plants of this family in both in-situ and ex-situ method. To meet the need fulfilled by these plants the plants need to be cultivated and protected by habitat conservation.

\section{Acknowledgement}

Authors are thankful to Sir Dr. M.L.Naik, Retd. Professor SOS in Life Science, Pt. RSU Raipur, ExCoordinator of Bastar and Sarguja University and Sir Dr A. Girolkar, Principal, Govt. D.B. Girls College, Raipur [C.G.] for their help and support. We are also thankful to the publication house for giving us the opportunity to publish our research work in your referred and reviewed research journal.

\section{References}

[1]. Agharkar, S.P, Medicinal Plants of Bombay presidency (Scientific Publishers, Jodhpur India) 1991.

[2]. Ambasta, S. P., The useful plants of India (Publication, and Information on: CSIR, New Delhi) 1986.

[3]. Banerjee M (2002) Public policy on Ayurveda. Economic and political weekly. 37: 1136-1146.

[4]. Cotton, C.M., Ethnobotany : Principles and Applications (John Wiley and Sons, Chichester. New York. Pp-6-8, 15-18.) 1996.

[5]. Dastur J F, Useful Plants of India and Pakistan (Taraporevala and sons, Bombay, India) 1964.

[6]. Duke J A, Handbook of Legumes of World Economic Importance (New York: Plenum Press) 1981

[7]. Duthie J F, Flora of the upper Gangetic plain and the adjacent Siwalik and sub Himalayan Tracts (BSI. Calcutta.) 1903.

[8]. $\quad$ Hooker J D, The Flora of British India, Vols 2 (Reeve \& Co., London, England) 1872-97.

[9]. Jain S K, Dictionary of Indian folk Medicine and Ethnobotany (Deep publications, New Delhi, India) 1991.

[10]. Jain S K, A Manual of Ethnobotany $\left(2^{\text {nd }}\right.$ Ed.) (Scientific Publishers, Jodhpur) 1995.

[11]. Jain S.K \& Jain A K, Introduction To Ethnobotany (Deep Publications ) 2013

[12]. Jain, S.K. \& Rao, R.R.A Handbook of field and Herbarium methods.( Scholarly Publications) 1977

[13]. Khare, C.P. Indian Medicinal Plants. (Springer) ISBN-978-0-387-70637-5. 2007

[14]. Lewis G B, Schrire B, MacKinder \& M. Lock (eds) Legumes of the world (Royal Botanical Gardens, Kew, UK) 2005.

[15]. Martin J N, Comparative Morphology of Some Leguminosae. Botanical Gazette vol-58 (University of Chicago. pp 154-167.)1913.

[16]. Nair N C \& Khanna K K, Floristic Diversity of Chhattisgarh (Bisen Singh Mahendra Pal Simgh, Dehradun) 2005.

[17]. Oommachan M, Flora of Bhopal (J.K. Jain Brothers, Bhopal) 1976.

[18]. Panigrahi G \& Murti S K , Flora of Bilaspur district, M.P(Botanical survey of India, Calcutta) 1998

[19]. Sanjappa M, Legumes of India ( Bishen Singh Mahendra Pal Singh, Dehradun, 338 pp) 1992.

[20]. Singh A N, Caesalpiniaceae. In: Verma D M, Balakrishnan N P \& Dixit R D (eds.), Flora of Madhya Pradesh (Botanical Survey of India, Calcutta, pp. 412-416) 1993

[21]. The Wealth of India(1950). A Dictionary of the IndianRaw Materials \& Industrial Products. Vol-I-IV, ICSIR, New Delhi, India.

[22]. Verma D M, Balkrishan N P \& Dixit R D, Flora of Madhya Pradesh Vol I (Botanical survey of India. Calcutta. Pp. 1-668.) 1994.

[23]. Verma D M, Pant P C \& Hanfi M I, Flora of India Series:3-Flora of Raipur, Durg and Rajnandgaon (Botanical survey of India, Calcutta) 1985. 